\title{
An Interview with Associate Professor Jill Bevan-Brown
}

\author{
By Paul Mitchell
}

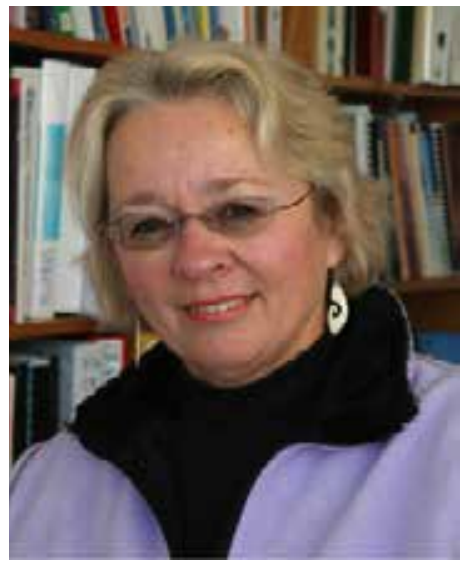

Interviewing Jill Bevan-Brown was a pleasant and interesting way to spend a Sunday afternoon. I started by asking Jill what she been doing recently and was delighted to hear she had launched a book during the past week. Jill told me she had started the book in 1989 and because she simply didn't have the time, she would have still been writing it for the next ten years if she hadn't brought others on board to write their contributions too. In the latter half of 2013 Jill contacted five other Māori women academics, Doctors Mere Berryman, Huhana Hickey, Sonja Macfarlane, Kirsten Smiler and Tai Walker to assist with the writing. Including Jill, the authors represented five different universities and were each able to share their particular expertise through the book. This book, Teaching Māori Children with Special Needs - He Mahi Whakahirahira, has its foreword written by Linda Tuhiwai Smith, Professor of Māori at the University of Waikato, and is published by NZCER. Jill says the strength of the book is its shared authorship and the fact that it is based on research studies that included over one thousand Māori with special needs and their whānau.

Jill officially retired in December 2014 to support her husband who has Lewy Body Dementia, but is still working with her PhD students and teaching a short course on ASD associated with the Post Graduate Diploma in Specialist Teaching. Jill has just handed over to Dr James Graham the role of co-ordinator for Māori, Pasifika and Multi-Ethnic input into the qualification. Jill was working in tandem with Sonja Macfarlane in this role; Jill the Massey co-ordinator and Sonja for Canterbury University.

Jill's career in education formally started when she went to teachers college, aged sixteen. There wasn't the same ease of choice of occupations then for women, it was pretty much nurse or teacher and she says she drifted into teaching. Later in teaching Jill became interested in children with special needs as a natural flow-on of her early lessons in social justice. 'My father was an All Black who wasn't allowed to go to South Africa'.

Jill remembers her father, Vince Bevan, not being able to go on the tour because he was Māori and also remembers being indignant because her family was proud of being Māori so she couldn't understand what was happening. This unfairness, combined with her Catholic upbringing that focused on service before self, and family and friends who had struggled in the education system were all influences that led Jill to special education and helping those in need, and noticing and taking action where she saw issues of social justice.

Who Jill is and who and where she came from saw her being asked to be in a debating team in 1969 in her first year at Wellington Teachers' College. Asked because she was Vince Bevan's daughter, with the moot of the debate being about apartheid.

Jill always knew that she should help make people's lives better.

After Teachers College, Jill taught in Titahi Bay and Porirua in Wellington before doing the big OE for three years. Amongst other experiences she lived on a Kibbutz in Israel and taught in London. On her return home, Jill became a Guidance and Learning Unit Teacher (GLU), at the beginning of the GLU initiative, for the intermediates in Porirua, Titahi Bay and Tawa in Wellington.

Later, Jill had four children, in the middle of which she moved to Otaki and got a job at the Otaki Health Camp. Her whakapapa is to Otaki. While at Health 
Camp the one year specialist teaching diploma came up at Palmerston North College of Education and Jill took a year off Health Camp to do this. Jill never returned to Health Camp because she took over the Māori papers and special education papers at PNCE which later merged with Massey University. She did her PhD when she worked at Massey University. Jill went on to develop the Bachelor of Education in Special Education and teaching. This was her main job up until the Post Graduate Diploma in Special Teaching was introduced.

Over this time, Jill was also actively engaged in over 20 different research and evaluation projects including studies of Māori perspectives of giftedness, intellectual disability, Autism Spectrum Disorder and vision impairment. A highlight of these various studies was talking to, and working with, hundreds of Māori children with special needs, their parents and whānau. This included gifted children, who, from a Māori perspective, are considered to have special needs. Jill stated that she has been "blown away by the dedication and resilience of many parents of children with special needs who work tirelessly for their children often against great odds, ignorance and prejudice". In 2007 she joined forces with two such parents, Bernie Wastney and Gayle Te Kooro-Baker to form the PAI4ASD Charitable Trust which produced the DVD "In My Shoes". To date, twenty two thousand free copies of this DVD have been distributed on request to people and schools throughout New Zealand and overseas. Jill says she has been inspired by people in all areas of her work. 'I have been blessed to work with committed, knowledgeable people and have learnt such a lot from them. Mainly women, some men'.

In retirement Jill will still be reading and keeping up to date. 'You don't stop thinking when you retire. There's plenty more to learn and do'. Jill likes Mahatma Gandhi's take on life, 'Yes, but that was last week, I've learnt a lot since then'. Knowledge grows, and along with this, beliefs and opinions can change.

Jill concluded our interview by telling me, 'What I have achieved so far in my life has been because of my family and the wonderful relationships I have with people who have supported me and enabled me to do things that I couldn't have done by myself. This is the message - we are very aware of the importance now of the relationships teachers have with children. We can only be optimally effective if we have a good relationship with children. Children will bend over backwards for people who genuinely show care for them. We need to ensure that we show the same care in relationships we have with the adults we work with. Learning about each other increases the chance that people can work, support and help each other, through the trust that is built. Strong relationships in a group make for a stronger group. It's not just making us more effective with students but with people generally'.

In caring for her husband, Jill is positive about the opportunity this brings to her to celebrate all of the dimensions of this man that Lewy Body Dementia cannot change, and her commitment to him and studying the most effective supports that can be put in place for people with this condition will no doubt provide research and insights for future generations.

\section{Biography: Jill Bevan-Brown PhD}

Jill Bevan-Brown is a descendent of the Ngāti Raukawa, Ngāti Wehiwehi, Ngai te Rangi \& Ngāti Awa ki Waikanae tribes of Aotearoa/New Zealand. She recently retired as an Associate Professor at the Institute of Education at Massey University where she had worked since 1990. In her long and distinguished career, Associate Professor Bevan-Brown has produced numerous books, journal articles and other quality-assured publications and directed research and professional development projects. She has delivered keynote addresses nationally and internationally and has been the recipient of awards and accolades. In 2012, she received the Inaugural Te Manu Kotuku Award presented by GiftEDnz in recognition of her outstanding service and contribution to the education and development of gifted and talented children and young people in Aotearoa New Zealand and in 2013, the NZARE Te Tohu Pae Tawhiti an award for Māori researchers who have made a contribution to education research that is both outstanding and long-standing.

\section{INTERVIEWER PROFILE}

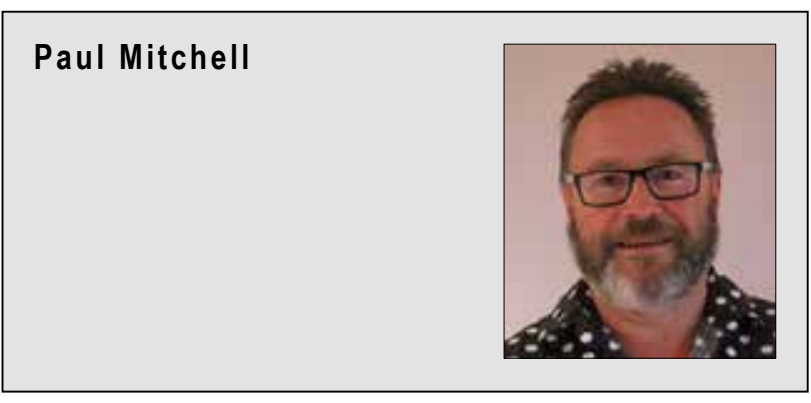

Paul Mitchell is the cluster manager for Resource Teacher: Learning \& Behaviour (RTLB) Cluster 16 based at Nawton School in Hamilton, and has worked since 1982 as a mainstream class teacher, principal, special education advisor for MOE, and an RTLB. When not working, Paul enjoys time sailing in the Hauraki Gulf, and assisting the Hamilton Operatic Society, of which he is President.

\section{Email: pgm100@xtra.co.nz}

